\title{
Reviewer Acknowledgements for Global Journal of Health Science, Vol. 13, No. 9
}

Global Journal of Health Science wishes to acknowledge the following individuals for their assistance with peer review of manuscripts for this issue. Their help and contributions in maintaining the quality of the journal are greatly appreciated.

Global Journal of Health Science is recruiting reviewers for the journal. If you are interested in becoming a reviewer, we welcome you to join us. Please contact us for the application form at: gjhs@ccsenet.org.

\section{Reviewers for Volume 13, Number 9}

Abiodun Adeniran, University of Ilorin, Nigeria

Ama Pokuaa Fenny, University of Ghana, Ghana

António Calha, Polytechnic Institute of Portalegre, Portugal

Ayesha Johnson, University of South Florida, United States of America

David John Lindsay, James Cook University, Australia

David Richard Walwyn, University of Pretoria, South Africa

Evangelia Mavrikaki, National \& Kapodistrian University of Athens, Greece

Farahnaz Amini, UCSI University, Malaysia

Gavric Zivana, University Banja Luka, Bosnia and Herzegovina

Georgann Valerie Weissman, Capella University, United States of America

Gunta Beta, Riga Stradins University, Latvia

Jingxian Cai, ICSA, ASA, ENAR, United States of America

Kartheek R Balapala, University Tunku Abdul Rahman, Malaysia

Lisa Scherer, University of Nebraska at Omaha, United States of America

Loray Daws, British Columbia Masterson Institute, Canada

Meng Zhao, Texas A\&M University at Corpus Christi, United States of America

Pedram Iranmanesh, Dentist, Independent Researcher, Iran

Pi-Ming Yeh, Missouri Western State University, United States of America

Samir Othman, Hawler Medical University, Iraq

Sara Melo, Queen's University Belfast, United Kingdom

Soontareeporn Meepring, Naresuan University, Thailand

Thanusin Saleeon, Mae Fah Lung University, Thailand

Tulyakul Phatcharapon, Boromarajonani College of Nursing, Thailand 